\title{
Treatment Options in Alzheimer's Disease: Maximizing Benefit, Managing Expectations
}

\author{
Martin R. Farlow ${ }^{a}$ Michael L. Miller ${ }^{b}$ Vojislav Pejovic ${ }^{b}$ \\ a Indiana University School of Medicine, Indianapolis, Ind., and b Prescott Medical Communications Group, \\ Chicago, III., USA
}

\section{Key Words}

Alzheimer's disease $\cdot$ Cholinesterase inhibitors .

Memantine $\cdot$ Pharmacotherapy $\cdot$ Combination therapy •

Antioxidants - Ginkgo biloba

\begin{abstract}
Alzheimer's disease (AD) is becoming an increasingly heavy burden on the society of developed countries, and physicians now face the challenge of providing efficient treatment regimens to an ever-higher number of individuals affected by the disease. Currently approved anti-AD therapies - the cholinesterase inhibitors and the N-methyl-D-aspartate receptor antagonist memantine - offer modest symptomatic relief, which can be enhanced using combination therapy with both classes of drugs. Additionally, alternative therapies such as nonsteroidal anti-inflammatory drugs, vitamin $\mathrm{E}$, selegiline, Ginkgo biloba extracts, estrogens, and statins, as well as behavioral and lifestyle changes, have been explored as therapeutic options. Until a therapy is developed that can prevent or reverse the disease, the optimal goal for effective $\mathrm{AD}$ management is to develop a treatment regimen that will yield maximum benefits for individual patients across multiple domains, including cognition, daily functioning, and behavior, and to provide realistic expectations for patients and caregivers throughout the course of the disease. This review provides a basic overview of approved AD therapies, discusses some pharmacologic and nonpharmacologic treatment strategies that are currently being investigated, and offers suggestions for optimizing treatment to fit the needs of individual patients.

Copyright $\odot 2008$ S. Karger AG, Basel
\end{abstract}

\section{Introduction}

Alzheimer's disease (AD) is the most common cause of dementia in the elderly, affecting approximately 4.5 million people in the United States alone [1]. As the incidence of AD in the United States and Europe is expected to double by the year 2050 [2, 3], developing successful treatments to this complex disease is becoming an everincreasing priority.

Approved treatments for $\mathrm{AD}$ - the cholinesterase inhibitors (ChEIs) and the N-methyl-D-aspartate (NMDA) receptor antagonist memantine - offer some symptomatic relief by targeting the cholinergic and glutamatergic neurotransmitter systems, respectively [4-9]. Other therapies, such as statins, vitamin E, Ginkgo biloba extracts, cognitive therapy, and psychological treatments have also been investigated clinically. Given the relatively limited arsenal of currently approved anti-dementia drugs, it is vital for physicians to make the best use of available options and, when appropriate, combine treatments in order to maximize benefit for the patient.

Dr. Martin Farlow receives grants from Eli Lilly \& Co., Novartis, Ono/ Pharmanet, Pfizer, Elan Pharm. He also is consultant for Abbott, Accera, Adamas, Cephalon Inc., Eisai Pharm, GlaxoSmithKline, Medivation, Memory Pharm., Merck Res. Labs., Neurochem, Novartis, Octapharma, Takeda, Toyama, Worldwide Clinical Trials and received honoraria from Eisai, Forest, Novartis, Pfizer as a member of Speakers' Bureau.

Drs. Michael Miller and Vojislav Pejovic work for Prescott Medical Communications Group, a contractor of Forest Laboratories, Inc.

\section{KARGER}

() 2008 S. Karger AG, Basel

Fax +41613061234 E-Mail karger@karger.ch www.karger.com www.karger.com/dem
Martin R. Farlow, MD

Department of Neurology, CL 291, Indiana University School of Medicine

541 Clinical Drive

Indianapolis, IN 46202-5111 (USA)

Tel. +1 317274 2893, Fax +1 317274 5873, E-Mail mfarlow@iupui.edu 
Table 1. Currently approved medications for the treatment of AD [10, 19, 27, 28, 32]

\begin{tabular}{|c|c|c|c|c|c|}
\hline & \multicolumn{4}{|c|}{ Second-generation ChEIs } & \multirow{3}{*}{$\begin{array}{l}\text { NMDAR } \\
\text { antagonist } \\
\text { memantine }\end{array}$} \\
\hline & \multirow[t]{2}{*}{ donepezil } & \multicolumn{2}{|l|}{ rivastigmine } & \multirow[t]{2}{*}{ galantamine } & \\
\hline & & oral & transdermal & & \\
\hline Dosing & once daily & twice daily & once daily & twice or once daily ${ }^{\mathrm{a}}$ & twice daily \\
\hline Starting & $5 \mathrm{mg} /$ day & $3.0 \mathrm{mg} /$ day & $4.6 \mathrm{mg} /$ day & $8 \mathrm{mg} /$ day & $5 \mathrm{mg} /$ day \\
\hline Maximum & $10 \mathrm{mg} /$ day & $12 \mathrm{mg} /$ day & $9.5 \mathrm{mg} / \mathrm{day}$ & $24 \mathrm{mg} /$ day & $20 \mathrm{mg} /$ day \\
\hline Titration interval & 4 weeks minimum & 4 weeks recommended & 4 weeks minimum & 4 weeks minimum & 1-week intervals \\
\hline Recommended doses & 5 and $10 \mathrm{mg} /$ day & $6-12 \mathrm{mg} /$ day & $9.5 \mathrm{mg} / \mathrm{day}$ & $16-24 \mathrm{mg} /$ day & $20 \mathrm{mg} /$ day \\
\hline Peak plasma concentration, $\mathrm{h}$ & $3-5$ & $0.8-1.7$ & $8-16$ & $0.5-1.5$ & $3-7$ \\
\hline Effect of food on drug absorption & none & $\begin{array}{l}\text { delays rate and } \\
\text { extent of absorption }\end{array}$ & none & $\begin{array}{l}\text { delays rate but not } \\
\text { extent of absorption }\end{array}$ & none \\
\hline \multirow[t]{2}{*}{ Hepatic metabolism } & CYP 2D6 & non-hepatic & non-hepatic & CYP 2D6 & primarily \\
\hline & CYP 3A4 & & & CYP $3 \mathrm{~A} 4$ & non-hepatic \\
\hline Elimination half-life, h & $\sim 70$ & 1.5 & 3.4 & $5-7$ & $60-80$ \\
\hline Drug-drug interactions & yes & none known & none known & yes & none known \\
\hline
\end{tabular}

See prescribing information for complete details. ${ }^{\text {a }}$ See text.

In this review, we discuss approved and investigational treatments for $\mathrm{AD}$, methods for maximizing clinical benefits, and strategies to effectively manage patient and caregiver expectations.

\section{ChEls: The First Class of Agents Approved for the Treatment of $A D^{1}$}

The first 15 years of AD pharmacotherapy were primarily focused on the widespread degeneration of acetylcholine (ACh)-containing neurons in the brains of affected patients. ChEIs were developed with the idea of inhibiting acetylcholinesterase (AChE), thereby enhancing cholinergic neurotransmission. Tacrine $\left(\right.$ Cognex ${ }^{\circledR}$, Warner-Lambert), the first ChEI approved by the US Food and Drug Administration (FDA) for the treatment of mild-to-moderate $\mathrm{AD}$, is no longer prescribed due to problems with tolerability and hepatotoxicity. Three second-generation ChEIs have been approved by the FDA for mild-to-moderate $\mathrm{AD}$, with one (donepezil) recently receiving approval for the treatment of severe $\mathrm{AD}$. All of the ChEIs provide modest but significant improvements in cognition and global patient functioning and, in spite of having different pharmacological profiles (table 1), are considered to have similar efficacy [4-7].

\footnotetext{
1 A thorough review of the efficacy data for the ChEIs and memantine is outside the scope of this article. For complete Phase III registration trials for these drugs, please refer to references $38-40,54,176-183$.
}

Donepezil (Aricept ${ }^{\circledR}$, Eisai; Pfizer, Inc.) has a long half-life (approximately $70 \mathrm{~h}$ ), which allows for once-daily dosing and can be administered in the form of an orally disintegrating tablet $[6,7,10]$. Evidence suggests that donepezil, in addition to providing cognitive and global benefits, may be moderately effective at alleviating functional problems and behavioral changes such as depression, anxiety, and apathy $[6,7]$. As with other ChEIs, the predominant side effects associated with donepezil are gastrointestinal (diarrhea, nausea; table 2) [10]. These symptoms are most severe during dose escalation, but may continue during maintenance therapy. Other reported side effects include anorexia, headaches, muscle cramps, fatigue, syncope, sleep disturbances, and urinary incontinence $[7,10,11]$. Donepezil is metabolized in the liver, but a portion of it (17\%) is excreted unchanged in the urine $[10,12]$. The $5-\mathrm{mg}$ dose can be given safely to patients with mild-to-moderate hepatic and renal impairment [13].

Rivastigmine (Exelon ${ }^{\circledR}$, Novartis Pharmaceuticals) [6, $7,14]$ selectively inhibits AChE in the central nervous system, and also inhibits butyrylcholinesterase $[7,15]$. It has been speculated that this additional mechanism may become important in advanced $\mathrm{AD}$ as $\mathrm{AChE}$ levels decline $[16,17]$, but recent measurements of butyrylcholinesterase activity in the synapses of patients with $\mathrm{AD}$ challenge this view [18]. Rivastigmine has a very short half-life in plasma and cerebrospinal fluid ( $1-2 \mathrm{~h})$, thus requiring twice-daily dosing [19-21]. Statistically significant benefits of rivastigmine have been observed for cognition, 
Table 2. Adverse events ${ }^{1}$ associated with the use of ChEIs and memantine in patients with $\mathrm{AD}^{*}[10,19,27,28,32]$

\begin{tabular}{|c|c|c|c|c|c|c|c|c|c|c|c|c|c|}
\hline \multirow[t]{4}{*}{ Adverse events ${ }^{1}$} & \multicolumn{4}{|c|}{ Donepezil } & \multicolumn{5}{|c|}{ Rivastigmine } & \multirow{2}{*}{\multicolumn{2}{|c|}{ Galantamine }} & \multirow{2}{*}{\multicolumn{2}{|c|}{ Memantine }} \\
\hline & \multicolumn{2}{|c|}{$\begin{array}{l}\text { mild to } \\
\text { moderate AD }\end{array}$} & \multicolumn{2}{|c|}{ severe $\mathrm{AD}$} & \multicolumn{2}{|l|}{ oral } & \multicolumn{3}{|c|}{ transdermal } & & & & \\
\hline & placebo & drug & placebo & drug & placebo & drug & placebo & capsule $^{2}$ & patch $^{2}$ & placebo & drug & placebo & drug \\
\hline & 355 & 747 & 392 & 501 & 868 & 1,189 & 302 & 294 & 291 & 801 & 1,040 & 922 & 940 \\
\hline Abdominal pain & - & - & - & - & 6 & 13 & - & - & - & 4 & 5 & - & - \\
\hline Accident & 6 & 7 & 12 & 13 & 9 & 10 & - & - & - & - & - & - & - \\
\hline Anorexia & - & - & 4 & 8 & 3 & 17 & 2 & 9 & 3 & 3 & 9 & - & - \\
\hline Anxiety & - & - & - & - & 3 & 5 & - & - & - & - & - & - & - \\
\hline Asthenia & - & - & - & - & 2 & 6 & 1 & 6 & 2 & - & - & - & - \\
\hline Confusion & - & - & - & - & 7 & 8 & - & - & - & - & - & 5 & 6 \\
\hline Constipation & - & - & - & - & 4 & 5 & - & - & - & - & - & 3 & 5 \\
\hline Depression & - & - & - & - & 4 & 6 & - & - & - & 5 & 7 & - & - \\
\hline Diarrhea & 5 & 10 & 4 & 10 & 11 & 19 & 3 & 5 & 6 & 7 & 9 & - & - \\
\hline Dizziness & 6 & 8 & - & - & 11 & 21 & 2 & 7 & 2 & 6 & 9 & 5 & 7 \\
\hline Dyspepsia & - & - & - & - & 4 & 9 & - & - & - & 2 & 5 & - & - \\
\hline Ecchymosis & - & - & 2 & 5 & - & - & - & - & - & - & - & - & - \\
\hline Fatigue & 3 & 5 & - & - & 5 & 9 & - & - & - & 3 & 5 & - & - \\
\hline Headache & 9 & 10 & - & - & 12 & 17 & 2 & 6 & 3 & 5 & 8 & 3 & 6 \\
\hline Infection & - & - & 9 & 11 & - & - & - & - & - & - & - & - & - \\
\hline Insomnia & 6 & 9 & 4 & 5 & 7 & 9 & - & - & - & 4 & 5 & - & - \\
\hline Malaise & - & - & - & - & 2 & 5 & - & - & - & - & - & - & - \\
\hline Muscle cramps & 2 & 6 & - & - & - & - & - & - & - & - & - & - & - \\
\hline Nausea & 6 & 11 & 2 & 6 & 12 & 47 & 5 & 23 & 7 & 9 & 24 & - & - \\
\hline Pain & 8 & 9 & - & - & - & - & - & - & - & - & - & - & - \\
\hline Somnolence & - & - & - & - & 3 & 5 & - & - & - & - & - & - & - \\
\hline Urinary tract infection & - & - & - & - & 6 & 7 & - & - & - & 7 & 8 & - & - \\
\hline Vomiting & 3 & 5 & 4 & 8 & 6 & 31 & 3 & 17 & 6 & 4 & 13 & - & - \\
\hline Weight decrease & - & - & - & - & - & - & 1 & 5 & 3 & 2 & 7 & - & - \\
\hline
\end{tabular}

* Information taken from Prescribing Information for each drug. ${ }^{1}$ Adverse events reported in at least $5 \%$ of patients receiving drug and at a higher frequency than placebo-treated patients (the 10 most frequently occurring adverse events for each drug are indicated in bold). ${ }^{2}$ Capsule: $6 \mathrm{mg} /$ day; patch: $9.5 \mathrm{mg}$ /day.

global function, and activities of daily living (ADLs) [22], and the drug also may improve attention focusing [7]. Moreover, a recent study has demonstrated that treatment with rivastigmine may delay the onset of behavioral symptoms and thus reduce the risk of initiating therapy with an antipsychotic [23]. The side effect profile for rivastigmine varies with dosing; in clinical trials designed to achieve the maximum tolerated dose, up to $50 \%$ of individuals in higher-dose groups experienced cholinomimetic side effects [24]. As with other ChEIs, gastrointestinal side effects associated with rivastigmine are common (vomiting, nausea, diarrhea, anorexia, abdominal pain; table 2), but some can be circumvented using a slower dose-titration scheme, upwardly titrating monthly rather than every 2 weeks [25]. Other notable side effects include dizziness, headache, and fatigue (table 2). Rivastigmine metabolism is almost completely (97\%) nonhepatic (primarily occurring through cholinesterase-mediated hydrolysis) [14], so possibilities of metabolic drug-drug interactions are minimal. In July 2007, the FDA approved a transdermal patch delivery system for rivastigmine, which demonstrated similar efficacy but better tolerability than the oral preparation in a clinical trial $[26,27]$.

Galantamine (Razadyne ${ }^{\mathrm{TM}}$, previously Reminyl ${ }^{\circledR}$, Ortho-McNeil) $[6,7,28]$, in addition to inhibiting AChE, allosterically binds nicotinic ACh receptors, thereby modulating the effects of ACh [29]. While binding nicotinic ACh receptors could influence neuronal processes, the clinical benefit of this mechanism has not been established. Traditional dosing is twice daily, and an extended release daily formulation is now available, allowing once daily dosing. Galantamine has been shown to provide 
some stabilization on measures of global functioning, cognition, behavior, and ADLs [30], although studies investigating its effects on behavior and ADLs have produced inconsistent results [30]. Approximately 30\% of galantamine is excreted unchanged in urine, whereas the rest is metabolized by hepatic enzymes [31]. Dose reduction is recommended in patients with moderately impaired hepatic or renal function [28]. The most commonly reported adverse events include nausea, vomiting, diarrhea, anorexia, and dizziness (table 2) [28]. Other reported side effects include depression, headache, and weight decrease (table 2). In July 2005, the commercial name of galantamine was changed from Reminyl to Razadyne, in an effort to avoid confusion and dispensing errors with the diabetes treatment, Amaryl.

\section{NMDA Receptor Antagonists: The Second Class of Agents Approved for the Treatment of AD}

Memantine (Namenda ${ }^{\circledR}$, Forest Laboratories, Inc.) [32], the first compound approved for patients in the moderate-to-severe stages of $\mathrm{AD}$, is a moderate-affinity, uncompetitive antagonist of the NMDA receptors (NMDARs). Glutamatergic dysfunction can lead to an excessive influx of calcium ions through NMDARs, leading to neuronal death through mechanisms that are not clearly understood [33]. Such 'excitotoxicity' has been implicated in AD [34]. The pharmacological properties of memantine are believed to prevent NMDAR-mediated excitotoxicity, while permitting normal synaptic activity [35]. The half-life of memantine in plasma is approximately 70 $\mathrm{h}$, which theoretically allows for once-daily dosing; however, the manufacturer, following established procedures, recommends two daily doses of $10 \mathrm{mg}$ each [32].

Memantine treatment of patients with moderate-tosevere AD has been shown to confer significant benefits on cognition, ADLs, global outcomes, and behavior (particularly agitation and aggression) when administrated either alone or in patients already receiving donepezil [ 9 , 36-40]. Memantine has also been investigated in patients with mild-to-moderate $\mathrm{AD}$, demonstrating significant results on cognition, behavior, and global status in one trial [41]; however, the FDA recently denied approval for this indication as other trials suggest that memantine may not be efficacious at this stage of the disease $[9,42]$. Memantine is safe and well tolerated, and trial discontinuation rates due to adverse events in memantine-treated patients are comparable to those in placebo groups [32]. In contrast to the ChEIs, gastrointestinal adverse events are rare. The most commonly reported adverse events that occur more frequently with memantine than placebo include dizziness, headache, confusion, and constipation (table 2) [32]. Memantine is primarily excreted unchanged in urine (48\%) [32], although in vitro evidence suggests the possibility of hepatic metabolism as well [43]. No metabolic interactions with other drugs have been observed with memantine [32] (table 1). Medications that alkalize urine may reduce the renal elimination of memantine, and dose reductions are recommended for patients with severe renal impairment $[32,44]$.

\section{Other Therapeutic Options in AD}

While the ChEIs and memantine have been designed to affect specific aspects of chemical neurotransmission, other therapies seek to target biochemical stressors, such as inflammation, oxidation, and the disruption of hormonal processes, all of which have been implicated in the neuronal loss observed in AD [8]. Some of the many therapies investigated for their potential to prevent the onset, delay progression, or reverse $\mathrm{AD}$ include anti-inflammatory drugs, antioxidants, selegiline, G. biloba, estrogen replacement, statins, and compounds designed to inhibit amyloid and tau neuropathology. Currently, efficacy data for each of these are either largely negative or inconclusive (most studies of compounds designed to inhibit amyloid or tau neuropathology are preliminary or still in progress).

It has been hypothesized that inflammation, likely caused (at least in part) by amyloid plaques, contributes to neuronal damage and eventual loss of synaptic function $[45,46]$. Epidemiological studies have demonstrated a lower incidence of $\mathrm{AD}$ in patients regularly using nonsteroidal anti-inflammatory drugs (NSAIDs), suggesting that NSAID use may be protective against AD [47]. However, prospective trials evaluating NSAID use did not reveal a symptomatic benefit in patients with $\mathrm{AD}[48,49]$ or mild cognitive impairment (MCI) [50,51], and a trial investigating a potential preventative role for naproxen and celecoxib was halted due to concerns over cardiovascular risks [52].

Another alternative approach involves protection against cellular damage caused by oxidative stressors. As markers of oxidative injury are evident in postmortem brain tissue of patients with AD [53, 54], it has been suggested that oxidative processes are involved in the disease pathogenesis. Antioxidants that have been investigated for their potential to reduce the risk of $\mathrm{AD}$ include vitamins $\mathrm{A}, \mathrm{C}$, and $\mathrm{E}$, coenzyme $\mathrm{Q}$, and selenium $[8,55,56]$. Clinical 
trials with vitamin $\mathrm{E}$ have produced the most consistent results, suggesting that it may be the most promising antioxidant for delaying the onset or slowing the progression of $\mathrm{AD}[57,58]$. As a result of these findings, AD treatment guidelines issued by the American Academy of Neurology in 2001 advised considering vitamin $\mathrm{E}$ as an adjunctive treatment [24]. However, in a more recently published large, double-blind, placebo-controlled trial in patients with MCI, no advantage for vitamin E over placebo regarding rate of cognitive decline or disease progression was seen during the 3-year course of the study [59]. Since recent evidence also suggests that high doses of vitamin $\mathrm{E}$ $(\geq 400$ IU/day) may be associated with higher all-cause mortality rates [60], a more comprehensive clinical evaluation is required before the risk-benefits ratio of vitamin $\mathrm{E}$ supplementation in $\mathrm{AD}$ can be determined.

A small number of clinical trials have also indicated that selegiline, a monoamine oxidase B inhibitor with antioxidant properties used for treating patients with Parkinson's disease [61], may be useful for the treatment of AD. In a long-term clinical trial, selegiline-treated patients demonstrated significant improvement on the Clock Draw Test and on the Mini-Mental Status Examination (MMSE) [62]. Clinical trial results have also indicated that treatment of $\mathrm{AD}$ with either selegiline, vitamin $\mathrm{E}$ or both may slow the progression of the disease [58]; however, a recent Cochrane meta-analysis of 17 trials of selegiline for $\mathrm{AD}$ found very few significant treatment effects and recommended that no further studies need to be conducted [63].

G. biloba extract, a popular herbal medication, is widely used for its potential cognitive and neuroprotective effects [64]. It has also been associated with antioxidant properties and inhibition of platelet-activating factor [65]. While ginkgo has been promoted as a memory enhancer for a number of years, its efficacy in patients with $\mathrm{AD}$ has not been validated by consistent data [66]. Several clinical studies have revealed a potential benefit of ginkgo for treatment of patients with $\mathrm{AD}$ [66-68]; however, a recent randomized, double-blind, placebo-controlled trial involving 513 patients did not demonstrate significant efficacy over placebo [69]. An ongoing prevention trial aimed at evaluating the potential effect of ginkgo on delaying progression to $\mathrm{AD}$ may reveal its utility in prodromal stages of dementia (ClinicalTrials.gov Identifier: NCT00010803; scheduled completion date: July 2009). G. biloba extract is generally well-tolerated: previous concerns regarding risk of hemorrhage due to inhibition of platelet-activating factor [70] have proven to be unfounded [69].
Observational studies have revealed a lower incidence of $\mathrm{AD}$ in postmenopausal women taking estrogen, suggesting that estrogen may have a protective role in $\mathrm{AD}$ [71]. However, recent studies indicate that the combination of estrogen and progestin, or estrogen alone, may in fact increase the risk for dementia and adversely effect cognition [72, 73]. Estrogen supplementation has also been linked to an increased risk of stroke, cancer, and other health problems [71, 74, 75]. Consequently, the Women's Health Initiative concluded in 2003 that the risks accompanying estrogen-progestin replacement therapy outweigh the potential benefits [72]. However, it should be noted that data from a smaller subsequent trial suggest that the timing of HRT in respect to the onset of menopause may be critical: early HRT initiation was associated with cognitive benefits compared to later initiation, whereas later initiation was associated with cognitive decline on the MMSE compared to participants who did not use HRT [76]. While debate continues over other potential benefits of hormone replacement therapy, it is not currently recommended specifically for the prevention or treatment of AD.

Epidemiological evidence has also revealed a decreased incidence of $\mathrm{AD}$ in patients taking the cholesterol-lowering drugs known as statins [77], thereby prompting investigation of their utility as an $\mathrm{AD}$ therapy [78]. A small prospective, double-blind, placebo-controlled trial of simvastatin in $A D$ demonstrated a reduced level of $\beta$ amyloid in the cerebrospinal fluid of patients with mild, but not moderate AD [79]. A similar trial found that patients with $\mathrm{AD}$ treated with atorvastatin performed significantly better than placebo-treated patients on a measure of cognition at 6 months (but not 12 months) [80]. Despite these results, it is not recommended that statins be used specifically for AD treatment. It has been suggested that patients with AD may be overly susceptible to adverse effects of statins due to pre-existing alterations in signal transduction and energy metabolism [81], although this has not been clinically verified. Future studies are expected to clarify the role of cholesterol and cholesterolprocessing pathways on $\mathrm{AD}$ progression and to ascertain whether the putative effects of statins in $\mathrm{AD}$ are related to their lipid-lowering properties. Regardless of age or risk of dementia, all individuals are advised to maintain cholesterol within recommended levels.

Many studies are underway to investigate biochemical and immunological methods for blocking one or more of the steps involved in amyloid and neurofibrillary pathology. Such therapeutic approaches may ultimately lead to additional ways of deterring, preventing, or altering the

Farlow/Miller/Pejovic 
progression of $\mathrm{AD}$; however, they will be required to undergo rigorous preclinical and clinical evaluation before being approved by the FDA. Most of those approaches are in relatively early stages of development, and it is unlikely that they will be available for at least a few more years.

\section{Nonpharmacological Approaches}

In addition to pharmacological approaches to $\mathrm{AD}$, a number of nonpharmacological methods have also been investigated. Although many of these studies have been poorly controlled and not subjected to the same rigorous criteria as trials of pharmaceutical agents [82], recent evidence suggests that there may be a role for various types of cognitive training and psychological intervention in the treatment of AD. A meta-analysis [83] showed that various cognitive therapy methods may improve or slow the rate of decline of cognitive and functional abilities in patients with $\mathrm{AD}$, and that restorative strategies, which are designed to restore functioning through repeated cognitive challenges, are typically more effective than compensatory strategies designed to 'work around' cognitive deficits [83]. A Cochrane meta-analysis of trials using reality orientation, in which patients are regularly presented with cues relating to their environment, also suggested potentially significant benefits for patients [84]. More recently, in a trial involving untreated patients with $\mathrm{AD}$, participants undergoing regular, intensive reality orientation and cognitive stimulation demonstrated better cognitive performance than the patients in the control group [85]. Such gains may be maintained for several months after the cessation of the treatment, although data on the persistence of such benefits are sparse [83]. Furthermore, psychosocial interventions such as caregiver support, counseling, education, and environmental modifications that minimize stressful situations for patients with $\mathrm{AD}$ have also been shown to minimize both patient behavioral problems [86] and caregiver distress (see below) [87]. As a caveat, it should be noted that it is often difficult to ascertain whether the benefits of cognitive therapy in $\mathrm{AD}$ are due to the methods themselves or the general stimulation of patients through regular interpersonal interactions with caregivers, family members, and health care professionals [83].

\section{Maximizing Benefit}

Ultimately, the hope for a truly revolutionary AD therapy lies in the potential of some pipeline compound to prevent or delay the onset of the disease. Until this pos- sibility is realized, it is important that practicing physicians optimize available symptomatic therapies in order to provide the best possible treatment regimen. Clinical issues that may influence the effectiveness of therapy include early and efficient diagnosis, behavioral or lifestyle modifications, patient compliance, and sequential or combinatorial therapeutic approaches with available drugs.

\section{Early and Efficient Diagnosis}

Pathological changes and neuronal degeneration in AD begin many years before a clinical diagnosis can be made [88-91]. Since such changes are likely cumulative, diagnosis and intervention at an early, preclinical stage of the disease can be of paramount importance in preserving cognitive function [92].

The first signs of cognitive complaints can indicate a syndrome called mild cognitive impairment (MCI) [93, 94], which is defined as a 'cognitive decline greater than that expected for an individual's age and education level but that does not interfere notably with activities of daily life' [95]. The significance of MCI is well illustrated by an observation that 80 -year-old patients with MCI can be expected to progress to $\mathrm{AD}$ at a rate of $12 \%$ per year, compared to $2 \%$ per year for control, age-matched subjects [96]. A 2003 conference dedicated to MCI resulted in a diagnostic algorithm that can be used to identify four MCI subtypes [93, 94], one of which, the single-domain amnestic MCI (also referred to as 'amnesic MCI' or 'aMCI'), is particularly associated with a high probability of conversion to $\mathrm{AD}$ : one study found a conversion rate to $\mathrm{AD}$ of approximately $49 \%$ (over 2.5 years) for patients with amnestic MCI, compared to approximately $27 \%$ for patients with nonamnestic forms [97]. The identification of factors that best predict the conversion from MCI to $\mathrm{AD}$ is an area of intense research [97-101].

Current expert opinion recommends careful monitoring of patients who show symptoms of amnestic MCI, since they may have reached a prodromal stage of $\mathrm{AD}[95$, $102,103]$. Although standard diagnostic tools for dementia, such as the MMSE, may not be sensitive enough to detect memory problems indicative of MCI [95], efforts are being made to develop more effective diagnostic tools [104]. In addition, corroboration and characterization of patient memory complaints from family members or other caregivers can help identify individuals at the highest risk of progressing from MCI to AD [105-108]. Finally, emerging brain imaging techniques hold the promise of an early, accurate, and sensitive detection of the underlying $\mathrm{AD}$ pathology [109-112], although at this point the 
cost-effectiveness of these tools is still a matter of contention [113-115].

For individuals whose changes in cognitive, functional, or behavioral performance indicate progression toward $\mathrm{AD}$, there are numerous standard and validated evaluation tools for measuring the degree of impairment and monitoring progression of the disease. The MMSE and the Clock Drawing Test are most commonly used in a clinical setting; however, a recent study comparing 13 screening instruments with an administration time of 10 min or less suggests that the Mini-Cog, the Memory Impairment Screen, and the General Practitioner Assessment of Cognition show potential for widespread clinical use due to ease of administration and interpretation, patient-friendliness, sensitivity, specificity, and freedom from factors such as age, education, and language [116]. A recently developed questionnaire called the St. Louis University Mental Status Examination, similar to the MMSE but possibly more sensitive to MCI [117], also shows promise for diagnostic purposes, although additional validation is required. With the standardization of basic clinical evaluation tools, practitioners should be able to evaluate patients more easily, potentially enabling earlier diagnosis, staging, and treatment initiation. To emphasize the importance of early and accurate diagnosis of dementia, an international working group has recently proposed new diagnostic criteria for AD that include neuroimaging, biomarkers, and genetic evidence [118].

\section{Patient and Caregiver Lifestyle}

Lifestyle and environmental factors such as diet, education, and occupational complexity have all been investigated for correlations to AD [119]. For example, a retrospective analysis of approximately 10,000 participants of a healthcare system in California showed that an increased adiposity (defined as the body mass index of at least 25) in midlife ( $40-45$ years of age) is associated with a significantly greater risk of developing $\mathrm{AD}$ or vascular dementia, in a manner independent of comorbidities $[120,121]$. According to a Swedish study of twins, low education represents a risk factor for dementia independent of genetic influences [122]. Both of these findings are mirrored by another Scandinavian study, which showed that future dementia could be significantly predicted by high age, low education, hypertension, hypercholesterolemia, and obesity [123]. In addition, epidemiological studies suggest that the regular consumption of food rich in antioxidants or $\omega$-unsaturated fatty acids, such as red wine $[124,125]$, fruit and vegetable juices [126], green tea
[127], coffee $[128,129]$, curry $[130,131]$, and fish [132$134]$ is associated with a lower risk of AD.

Activities involving complex cognitive functioning, such as reading, participating in board games, or playing musical instruments, may also help protect against the development of dementia [135]. In addition, regular physical activity has been associated with the maintenance of healthy brain function, increased neuronal survival, protection against neuronal injury, and a reduced risk of dementia in cognitively normal elderly persons [136-139]. Physical activity has been also associated with improved cognitive function in older adults with cognitive impairment and dementia, suggesting that exercise may continue to provide benefits even after diagnosis [140]. A recent review of lifestyle activities suggests that social networking, in addition to mental and physical activity, is also important to maintaining cognitive health [141]. Therefore, patients should be encouraged to maintain or initiate healthy lifestyles, including a balanced diet, increased mental and physical activities, and regular social contact with peers and family members.

Finally, since patients with $\mathrm{AD}$ become increasingly dependent on caregiver support as the disease progresses, a caregiver's own well-being constitutes an important goal of disease management. In a recent study of 406 caregivers over 18 years, nursing home placement of patients with AD was delayed by an average of 557 days in families that received enhanced caregiver support [142]. Several studies have shown that many types of intervention (cognitive-behavioral therapy, counseling, daycare, training of care recipient, and multicomponent interventions) can be beneficial for people who care for patients with AD [142-147]. Caregiver psychotherapy (counseling) and psychoeducational techniques such as caregiver stress and anger management, depression management, and programs designed to help the caregiver recognize and minimize stressful situations for patients, have proven particularly effective $[86,87]$. Caregivers should be directed to educational and support resources, such as the Alzheimer's Association website (http://www.alz.org), which contains a large amount of information about local resources, caregiver support, and patient care. The issue of caregiver burden has been largely overlooked until recently, and deserves the increased attention of healthcare policy makers and physicians alike [148].

\section{Optimizing Pharmacotherapy: Monotherapy}

Patients with $\mathrm{AD}$ often discontinue treatment due to side effects, a lack of initial efficacy, or the loss (or perceived loss) of efficacy during treatment [149]. Approxi- 
mately $51 \%$ of patients newly treated with an AD medication discontinue therapy within 4 months of treatment initiation [150], suggesting that many patients are not receiving optimal benefits from pharmacotherapy. The side effects associated with the use of ChEIs, which are primarily gastrointestinal (table 2), continue to provide a significant challenge to patient adherence. Some of these adverse effects can be minimized through a slower dosing scheme (titrating as slowly as every $4-6$ weeks) during the initial and escalation phases of treatment, or by administering the medication with food to retard the rapid stimulation of the cholinergic system [25] (except in the case of donepezil and transdermally delivered rivastigmine, for which the rate of absorption is not affected by food $[10,151])$. Since side effects associated with memantine use are less severe and less frequent, tolerability problems are not a common reason for discontinuance with this medication $[4,9]$.

As each ChEI has a distinct pharmacokinetic and pharmacodynamic profile, switching patients from one ChEI to another is a viable option in patients who have problems with long-term efficacy or tolerability of their initial medication $[149,152]$. In several studies, approximately $50 \%$ of patients who previously failed to respond to a ChEI demonstrated stabilization or improvement after switching to a different ChEI; in addition, a patient's response to one ChEI was not predictive of response to another $[5,149,152]$. In many cases, patients who switch medications are also less likely to experience cholinergic side effects [149]. The optimal procedure for switching remains to be determined, although some studies and guidelines suggest that the second drug may be administered as early as one day after the first has been discontinued [149]. In cases of poor tolerability with the initially prescribed medication, however, a washout period is recommended until side effects resolve [149]. One guideline suggests cessation of therapy for five half-lives (donepezil, 15 days; rivastigmine/galantamine, 2 days) before switching [6], although in most cases 1 week is sufficient [153]. Dose adjustments to the initial treatment should always be considered before switching medications, and a minimum treatment period of 6 months, with realistic treatment expectations (see below), is recommended in cases where a lack of efficacy is perceived [149].

Traditionally, patients with early-stage (mild-to-moderate) $\mathrm{AD}$ are prescribed ChEIs, while memantine is indicated for patients in moderate-to-severe stages of the disease. These lines are beginning to blur, however. The recent approval of donepezil for severe AD [154] will likely lead to increased ChEI use in late-stage $\mathrm{AD}$, and cur- rent practice suggests that patients should not discontinue ChEI therapy even after they progress to a more severe stage [155]. Additional studies involving patients with mild-to-moderate AD may also help clarify whether memantine can be effective in treating patients (or a subset of patients) in earlier stages of the disease $[9,41,42]$.

Despite the apparent advantages of beginning therapy as early in the disease process as possible, the ability of either the ChEIs or memantine to delay (or modify) disease progression, as opposed to merely providing symptomatic relief, remains unproven. The clinical efficacy of ChEIs in MCI is also being tested, but neither symptomatic nor disease-modifying effects have been established for the use of these drugs at such an early stage [30, 59, $156,157]$. Preclinical studies with memantine are consistent with a putative neuroprotective role [158], but this has yet to be demonstrated in patients. Until more data are available, practicing physicians must use their best judgment in determining the point at which pharmacotherapy is instituted, based on an individual patient's risks and needs.

\section{Optimizing Pharmacotherapy: Combination Therapy}

Combination therapy is commonly used in treating many other diseases, including cancer and HIV. Due to the complex nature of $\mathrm{AD}$ and the distinct mechanisms of action of the ChEIs, memantine, and alternative treatments, combination therapy may also be effective in $\mathrm{AD}$.

\section{Co-Administration of ChEIs and Memantine}

A randomized, double-blind clinical trial of memantine was performed in 404 patients with moderate-to-severe $A D$ who were already receiving stable doses of donepezil [39]. Participants who received both donepezil and memantine showed significantly better performance over those who received donepezil plus placebo in all domains assessed, which included measures of cognition, function (ADLs), behavior, psychiatric disturbance, and global condition. While most adverse events in both treatment groups were mild or moderate and judged to be unrelated to either study drug, the addition of memantine was associated with a lower incidence of several cholinergic adverse events in this study. Participants who received both drugs had a lower frequency of diarrhea, fecal incontinence, and discontinuance due to adverse events than those on donepezil alone, although the statistical significance of these differences was not addressed in this study [39].

Pilot combination studies have also been performed using memantine and the other ChEIs. A European post- 
marketing surveillance study demonstrated that memantine is well-tolerated in combination with donepezil, rivastigmine, and tacrine [159]. Co-therapy of memantine with galantamine in a 6-month prospective cross-sectional study was well-tolerated and resulted in no cognitive or functional deterioration during the course of treatment, according to caregiver reports [160]. Another recent pilot study investigating the efficacy and tolerability of memantine in patients with mild-to-moderate $\mathrm{AD}$ receiving stable rivastigmine treatment concluded that the addition of memantine resulted in additional cognitive benefits and was safe and well-tolerated [161]. A growing body of evidence suggests that adding memantine to ChEI therapy may produce additional cognitive, functional, and global benefits, accompanied by a negligible increase in risk of adverse effects. The possibility that memantine may also have an effect on improving the tolerability of ChEI treatment [39] merits further investigation in prospective trials. It should again be noted, however, that memantine is currently approved for patients with moderate to severe $\mathrm{AD}$, while rivastigmine and galantamine are currently approved for patients with mild to moderate AD.

\section{Co-Administration of Antidementia Therapy and}

Antipsychotics

While co-administration of ChEIs or memantine with antipsychotics and antidepressants is a standard practice for patients with behavioral disturbances in advanced stages of $\mathrm{AD}$ [24], the treatment of behavioral symptoms with atypical antipsychotics is considered off-label in geriatric patients, as these drugs are associated with an increased risk of death, falls and cerebrovascular adverse events in the elderly [162-164]. In such patients, nonpharmacologic interventions should be exhausted prior to prescribing drugs for these symptoms [for a review of many nonpharmacologic options, see 165]. Evidence also suggests that both memantine and the ChEIs may reduce or prevent the emergence of behavioral symptoms in $\mathrm{AD}$ patients [37, 166, 167], which may allow patients to either avert or reduce the usage of antipsychotic medications. It has been suggested that $\mathrm{AD}$ patients are particularly vulnerable to antipsychotic-induced cerebral neurotoxicity, so diminished antipsychotic use may be of particular relevance in this patient population [168].

Co-Administration of Traditional and

Nontraditional Therapies

As studies regarding the efficacy of agents such as vitamin E and G. biloba have not yet produced consistent results in clinical trials, it would be premature to recommend combining them with standard ChEI or memantine therapy. Although these and other agents may eventually be deemed effective and safe for patients with $\mathrm{AD}$, additional prospective trials will be required to determine their exact role in pharmacotherapy. However, there is an increasing body of evidence that nonpharmacological methods may ultimately become a useful supplement to current pharmacologic treatment. For example, a randomized, controlled, multicenter trial of reality orientation therapy in patients taking donepezil demonstrated significant improvements for patients receiving both treatments over those receiving donepezil alone [169]. As cognitive and behavioral methods pose little risk to patients and caregivers, and may provide benefits, caregivers should be encouraged to pursue these alternative strategies if desired. However, more rigorously controlled long-term studies will be required to determine which of these techniques, if any, can provide consistent benefits, and whether they should become a routine part of standard therapy.

\section{Managing Expectations}

Unrealistic expectations of patients and caregivers can negatively impact treatment compliance. When patients inevitably continue to decline despite therapeutic intervention, frustration is understandable; however, studies suggest that the benefits of therapy can be rapidly lost if treatment is discontinued [170], and in most cases even modest therapeutic effects provide justification for therapy maintenance [155]. Open-label extension trials have suggested continued benefits for up to 1 year with memantine [171] and for at least 3 years with each of the ChEIs [172-174]. Patients and caregivers should be aware that current pharmacotherapy responses are less than ideal, and expectations should center on slowing decline or delaying institutionalization rather than overall patient improvement. While current treatments for $\mathrm{AD}$ may lessen the symptomatic decline of the disease and provide an extension of independence in some cases, they cannot be considered disease-modifying or curative. Physicians must exercise caution when discussing treatments with patients and their caregivers, impressing upon them that the benefits of current pharmacologic treatments are rarely seen as an improvement in symptoms, but rather as an extension of patient independence. If patients and caregivers understand that a significant goal of treatment is to delay the onset of more severe 
symptoms or long-term care placement, treatment compliance may improve. Providing regular reassessment every 6 months is also crucial for tracking both the progression of the disease and the status of the caregiver [175].

Physicians should also assist patients and caregivers in recognizing that nontraditional treatments, such as ginkgo, vitamin $\mathrm{E}$, and selegiline, are not yet clinically validated as efficacious treatments. While some clinical evidence supports their use, many of the double-blind placebo-controlled trials to date have been negative. Continuing the prescribed treatment - along with a healthy diet, exercise (if possible), and regular contact with the physician - is the most realistic manner in which patients can control the symptoms of their illness.

\section{Conclusions}

The availability of approved pharmacotherapies (second-generation ChEIs and memantine) and the emergence of numerous alternative therapies have armed physicians with more treatment options for $\mathrm{AD}$ compared to just over a decade ago, when tacrine was the only available therapeutic option. Although prospective trials examining the role of agents such as NSAIDs, selegiline or estrogen-progestin combination in the prevention or treatment of $\mathrm{AD}$ have been largely negative, potential new therapeutics for $\mathrm{AD}$, including statins and agents that combat amyloid deposition and tau hyperphosphorylation, may one day be shown to provide protection against neurodegeneration. However, until new preventive or disease-altering medications are approved, physicians must optimize the use of available pharmaceutical and behavioral therapies. ChEIs are still the traditional first line of pharmacotherapy for mild-to-moderate AD, while memantine and donepezil are both indicated for moderate-to-severe AD. In instances where patients do not respond or have tolerability issues with a particular ChEI, changes in dose titration or switching of ChEIs can be attempted. Combinations involving memantine and ChEIs may produce additional benefits to patients without significantly increasing the risk of side effects, and future clinical trials may identify other agents that show efficacy for AD symptoms when used alone or as a part of combination therapy. In principle, therapeutic intervention should occur early in the disease, in order to slow or prevent symptom progression for as long as possible.

Patients and caregivers must maintain reasonable expectations regarding pharmacotherapy, and resources such as support groups and social networking can provide relief for both patients and caregivers. Cognitive and behavioral therapies may also play a role in improving patient cognition and function, diminishing caregiver stress, and delaying nursing home placement. As more is learned about the combinatorial effects of these and other potential therapeutic options at all stages of $\mathrm{AD}$, the ability to significantly impact disease progression may one day be realized.

\section{Acknowledgments}

The authors wish to thank Ms. Annalise Nawrocki and Dr. Kristen A. Andersen of Prescott Medical Communications Group for their assistance in the preparation and review of the manuscript.

Dr. Martin Farlow receives support from the NIH grant P30 AG10133.

\section{References}

$>1$ Hebert LE, Scherr PA, Bienias JL, Bennett DA, Evans DA: Alzheimer disease in the US population: prevalence estimates using the 2000 census. Arch Neurol 2003;60:11191122 .

-2 Hebert LE, Beckett LA, Scherr PA, Evans DA: Annual incidence of Alzheimer disease in the United States projected to the years 2000 through 2050. Alzheimer Dis Assoc Disord 2001;15:169-173.

-3 Wancata J, Musalek M, Alexandrowicz R, Krautgartner M: Number of dementia sufferers in Europe between the years 2000 and 2050. Eur Psychiatry 2003;18:306-313.
4 Birks J: Cholinesterase inhibitors for Alzheimer's disease. Cochrane Database Syst Rev 2006:CD005593.

5 Burns A, O’Brien J, Auriacombe S, Ballard C, Broich K, Bullock R, Feldman H, Ford G, Knapp M, McCaddon A, Iliffe S, Jacova C, Jones R, Lennon S, McKeith I, Orgogozo JM, Purandare N, Richardson $M$, Ritchie C, Thomas A, Warner J, Wilcock G, Wilkinson D: Clinical practice with anti-dementia drugs: a consensus statement from British Association for Psychopharmacology. J Psychopharmacol 2006;20:732-755.
6 Cummings JL: Use of cholinesterase inhibitors in clinical practice: evidence-based recommendations. Am J Geriatr Psychiatry 2003;11:131-145.

7 Farlow M: A clinical overview of cholinesterase inhibitors in Alzheimer's disease. Int Psychogeriatr 2002;14(suppl 1):93-126.

-8 Farlow MR: Utilizing combination therapy in the treatment of Alzheimer's disease. Expert Rev Neurotherapeutics 2004;4:799808 .

9 McShane R, Areosa Sastre A, Minakaran N: Memantine for dementia. Cochrane Database Syst Rev 2006:CD003154. 
10 Aricept $^{\circledR}$ : U.S. Prescribing Information. New York, Pfizer, 2006.

11 Dunn NR: Adverse effects associated with the use of donepezil in general practice in England. J Psychopharmacol 2000;14:406448.

12 Tiseo PJ, Perdomo CA, Friedhoff LT: Metabolism and elimination of $14 \mathrm{C}$-donepezil in healthy volunteers: a single-dose study. $\mathrm{Br} \mathrm{J}$ Clin Pharmacol 1998;46(suppl 1):19-24.

13 Seltzer B: Donepezil: a review. Expert Opin Drug Metab Toxicol 2005;1:527-536.

14 Exelon: U.S. Prescribing Information. East Hanover, Novartis, 2006.

15 Bullock R: The clinical benefits of rivastigmine may reflect its dual inhibitory mode of action: an hypothesis. Int J Clin Pract 2002; 56:206-214

16 Giacobini E: Cholinesterase inhibitors: new roles and therapeutic alternatives. Pharmacol Res 2004;50:433-440.

17 Giacobini E: Cholinesterases: new roles in brain function and in Alzheimer's disease. Neurochem Res 2003;28:515-522.

$\checkmark 18$ Kuhl DE, Koeppe RA, Snyder SE, Minoshima S, Frey KA, Kilbourn MR: In vivo butyrylcholinesterase activity is not increased in Alzheimer's disease synapses. Ann Neurol 2006;59:13-20.

19 Exelon $^{\circledR}$ : U.S. Prescribing Information. East Hanover, Novartis, 2006.

20 Farlow MR: Update on rivastigmine. Neurologist 2003;9:230-234.

-21 Gobburu JV, Tammara V, Lesko L, Jhee SS, Sramek JJ, Cutler NR, Yuan R: Pharmacokinetic-pharmacodynamic modeling of rivastigmine, a cholinesterase inhibitor, in patients with Alzheimer's disease. J Clin Pharmacol 2001;41:1082-1090.

22 Birks J, Grimley Evans J, Iakovidou V, Tsolaki M: Rivastigmine for Alzheimer's disease. Cochrane Database Syst Rev 2000: CD001191.

-23 Suh DC, Arcona S, Thomas SK, Powers C, Rabinowicz AL, Shin H, Mirski D: Risk of antipsychotic drug use in patients with Alzheimer's disease treated with rivastigmine. Drugs Aging 2004;21:395-403.

24 Doody RS, Stevens JC, Beck C, Dubinsky RM, Kaye JA, Gwyther L, Mohs RC, Thal LJ, Whitehouse PJ, DeKosky ST, Cummings JL: Practice parameter: management of dementia (an evidence-based review). Report of the Quality Standards Subcommittee of the American Academy of Neurology. Neurology 2001;56:1154-1166.

25 Jann MW, Shirley KL, Small GW: Clinical pharmacokinetics and pharmacodynamics of cholinesterase inhibitors. Clin Pharmacokinet 2002;41:719-739.

26 Winblad B, Cummings JL, et al: IDEAL: a 24 week placebo controlled study of the first transdermal patch in Alzheimer's disease rivastigmine patch versus capsule; presented at the 10th International Congress of Alzheimer's and Related Disorders (ICAD), Madrid, Spain, 2006.
27 Exelon Patch ${ }^{\circledR}$ : U.S. Prescribing Information. East Hanover, Novartis, 2007.

28 Razadyne ER: U.S. Prescribing Information. Titusville, Ortho-McNeil Neurologics, 2006.

29 Maelicke A, Albuquerque EX: Allosteric modulation of nicotinic acetylcholine receptors as a treatment strategy for Alzheimer's disease. Eur J Pharmacol 2000;393:165-170.

30 Loy C, Schneider L: Galantamine for Alzheimer's disease and mild cognitive impairment. Cochrane Database Syst Rev 2006: CD001747.

31 Mannens GS, Snel CA, Hendrickx J, Verhaeghe T, Le Jeune L, Bode W, van Beijsterveldt L, Lavrijsen K, Leempoels J, Van Osselaer N, Van Peer A, Meuldermans W: The metabolism and excretion of galantamine in rats, dogs, and humans. Drug Metab Dispos 2002; 30:553-563.

$32 \mathrm{Namenda}^{\circledR}$ : U.S. Prescribing Information. St. Louis, Forest Pharmaceuticals, 2006

33 Arundine M, Tymianski M: Molecular mechanisms of calcium-dependent neurodegeneration in excitotoxicity. Cell Calcium 2003;34:325-337.

34 Danysz W, Parsons C, Möbius HJ, Stöffler A, Quack G: Neuroprotective and symptomatological action of memantine relevant for Alzheimer's disease - a unified glutamatergic hypothesis on the mechanism of action. Neurotox Res 1999;2:85-97.

35 Rogawski MA, Wenk GL: The neuropharmacological basis for the use of memantine in the treatment of Alzheimer's disease. CNS Drug Rev 2003;9:275-308.

36 Cummings JL, Schneider E, Tariot PN, Graham SM: Behavioral effects of memantine in Alzheimer disease patients receiving donepezil treatment. Neurology 2006;67:57-63.

37 Gauthier S, Wirth Y, Mobius HJ: Effects of memantine on behavioural symptoms in Alzheimer's disease patients: an analysis of the Neuropsychiatric Inventory (NPI) data of two randomised, controlled studies. Int J Geriatr Psychiatry 2005;20:459-464

- 38 Reisberg B, Doody R, Stöffler A, Schmitt F, Ferris S, Möbius HJ: Memantine in moderate-to-severe Alzheimer's disease. N Engl J Med 2003;348:1333-1341.

39 Tariot PN, Farlow MR, Grossberg GT, Graham SM, McDonald S, Gergel I: Memantine treatment in patients with moderate to severe Alzheimer disease already receiving donepezil: a randomized controlled trial. JAMA 2004;291:317-324.

40 Winblad B, Poritis N: Memantine in severe dementia: results of the M-Best Study (Benefit and efficacy in severely demented patients during treatment with memantine). Int J Geriatr Psychiatry 1999;14:135-146.
-41 Peskind ER, Potkin SG, Pomara N, Ott BR, Graham SM, Olin JT, McDonald S, for the Memantine MEM-MD-10 Study Group: Memantine treatment in mild to moderate Alzheimer disease: a 24-week randomized, controlled trial. Am J Geriatr Psychiatry 2006;14:704-715.

42 Doody RS, Tariot PN, Pfeiffer E, Olin J, Graham SM: Meta-analysis of 6-month memantine trials in Alzheimer's disease. Alzheimer Dement 2007;3:7-17.

43 Micuda S, Mundlova L, Anzenbacherova E, Anzenbacher P, Chladek J, Fuksa L, Martinkova J: Inhibitory effects of memantine on human cytochrome P450 activities: prediction of in vivo drug interactions. Eur J Clin Pharmacol 2004;60:583-589.

44 Periclou A, Ventura D, Rao N, Abramowitz W: Pharmacokinetic study of memantine in healthy and renally impaired subjects. Clin Pharmacol Ther 2006;79:134-143.

45 van Gool WA, Aisen PS, Eikelenboom P: Anti-inflammatory therapy in Alzheimer's disease: is hope still alive? J Neurol 2003;250: 788-792.

46 McGeer PL, Rogers J, McGeer EG: Inflammation, anti-inflammatory agents and Alzheimer disease: the last 12 years. J Alzheimers Dis 2006;9:271-276.

47 in t' Veld BA, Ruitenberg A, Hofman A, Launer LJ, van Duijn CM, Stijnen T, Breteler MM, Stricker BH: Nonsteroidal antiinflammatory drugs and the risk of Alzheimer's disease. N Engl J Med 2001;345:1515-1521.

$\checkmark 48$ Zandi PP, Breitner JC: Do NSAIDs prevent Alzheimer's disease? And, if so, why? The epidemiological evidence. Neurobiol Aging 2001:22:811-817.

49 Aisen PS, Schafer KA, Grundman M, Pfeiffer E, Sano M, Davis KL, Farlow MR, Jin S, Thomas RG, Thal LJ: Effects of rofecoxib or naproxen vs. placebo on Alzheimer disease progression: a randomized controlled trial. JAMA 2003;289:2819-2826.

50 Thal LJ, Ferris SH, Kirby L, Block GA, Lines CR, Yuen E, Assaid C, Nessly ML, Norman BA, Baranak CC, Reines SA: A randomized, double-blind, study of rofecoxib in patients with mild cognitive impairment. Neuropsychopharmacology 2005;30:1204-1215.

51 Jelic V, Kivipelto M, Winblad B: Clinical trials in mild cognitive impairment: lessons for the future. J Neurol Neurosurg Psychiatry 2006;77:429-438.

52 U.S. Food and Drug Administration: FDA Issues Public Health Advisory Recommending Limited Use of Cox-2 Inhibitors. FDA Talk Paper, December 23. 2004;T04-61.

53 Pratico D, Delanty N: Oxidative injury in diseases of the central nervous system: focus on Alzheimer's disease. Am J Med 2000;109: 577-585.

54 Markesbery WR, Carney JM: Oxidative alterations in Alzheimer's disease. Brain Pathol 1999;9:133-146. 
-55 Nourhashemi F, Gillette-Guyonnet S, 68 Mazza M, Capuano A, Bria P, Mazza S: GinkAndrieu S, Ghisolfi A, Ousset PJ, Grandjean H, Grand A, Pous J, Vellas B, Albarede JL: Alzheimer disease: protective factors. Am J Clin Nutr 2000;71:643S-649S.

56 Luchsinger JA, Tang MX, Shea S, Mayeux R: Antioxidant vitamin intake and risk of Alzheimer disease. Arch Neurol 2003;60: 203-208.

- 57 Morris MC, Beckett LA, Scherr PA, Hebert LE, Bennett DA, Field TS, Evans DA: Vitamin $\mathrm{E}$ and vitamin $\mathrm{C}$ supplement use and risk of incident Alzheimer disease. Alzheimer Dis Assoc Disord 1998;12:121-126.

58 Sano M, Ernesto C, Thomas RG, Klauber MR, Schafer K, Grundman M, Woodbury P, Growdon J, Cotman CW, Pfeiffer E, Schneider LS, Thal LJ: A controlled trial of selegiline, alpha-tocopherol, or both as treatment for Alzheimer's disease. The Alzheimer's Disease Cooperative Study. N Engl J Med 1997;336:1216-1222.

- 59 Petersen RC, Thomas RG, Grundman M, Bennett D, Doody R, Ferris S, Galasko D, Jin S, Kaye J, Levey A, Pfeiffer E, Sano M, van Dyck CH, Thal LJ: Vitamin E and donepezil for the treatment of mild cognitive impairment. N Engl J Med 2005;352:2379-2388.

-60 Miller ER 3rd, Pastor-Barriuso R, Dalal D, Riemersma RA, Appel LJ, Guallar E: Metaanalysis: high-dosage vitamin E supplementation may increase all-cause mortality. Ann Intern Med 2005;142:37-46.

61 Lange KW, Riederer P, Youdim MB: Biochemical actions of 1-deprenyl (selegiline). Clin Pharmacol Ther 1994;56:734-741.

62 Filip V, Kolibas E: Selegiline in the treatment of Alzheimer's disease: a long-term randomized placebo-controlled trial. Czech and Slovak Senile Dementia of Alzheimer Type Study Group. J Psychiatry Neurosci 1999;24: 234-243.

63 Birks J, Flicker L: Selegiline for Alzheimer's disease. Cochrane Database Syst Rev 2003: CD000442.

64 Wold RS, Lopez ST, Yau CL, Butler LM, Pareo-Tubbeh SL, Waters DL, Garry PJ, Baumgartner RN: Increasing trends in elderly persons' use of nonvitamin, nonmineral dietary supplements and concurrent use of medications. J Am Diet Assoc 2005; 105:5463.

-65 Ahlemeyer B, Krieglstein J: Neuroprotective effects of Ginkgo biloba extract. Cell Mol Life Sci 2003;60:1779-1792.

66 Birks J, Grimley E, van Dongen M: Ginkgo biloba for cognitive impairment and dementia. Cochrane Database Syst Rev 2002;4: CD003120.

67 Napryeyenko O, Borzenko I: Ginkgo biloba special extract in dementia with neuropsychiatric features. A randomised, placebocontrolled, double-blind clinical trial. Arzneimittelforschung 2007;57:4-11. go biloba and donepezil: a comparison in the treatment of Alzheimer's dementia in a randomized placebo-controlled double-blind study. Eur J Neurol 2006;13:981-985.

69 Schneider LS, DeKosky ST, Farlow MR, Tariot PN, Hoerr R, Kieser M: A randomized, double-blind, placebo-controlled trial of two doses of Ginkgo biloba extract in dementia of the Alzheimer's type. Curr Alzheimer Res 2005;2:541-551.

70 Sierpina V, Wollschlaeger B, Blumenthal M: Ginkgo biloba. Am Fam Physician 2003;68: 923-926.

71 Nelson HD, Humphrey LL, Nygren $\mathrm{P}$ Teutsch SM, Allan JD: Postmenopausal hormone replacement therapy: scientific review. JAMA 2002;288:872-881.

72 Shumaker SA, Legault C, Thal L, Wallace RB, Ockene JK, Hendrix SL, Jones BN 3rd, Assaf AR, Jackson RD, Kotchen JM, Wassertheil-Smoller S, Wactawski-Wende J: Estrogen plus progestin and the incidence of dementia and mild cognitive impairment in postmenopausal women: the Women's Health Initiative Memory Study: a randomized controlled trial. JAMA 2003;289:26512662.

73 Rapp SR, Espeland MA, Shumaker SA, Henderson VW, Brunner RL, Manson JE, Gass ML, Stefanick ML, Lane DS, Hays J, Johnson KC, Coker LH, Dailey M, Bowen D: Effect of estrogen plus progestin on global cognitive function in postmenopausal women: the Women's Health Initiative Memory Study: a randomized controlled trial. JAMA 2003; 289:2663-2672.

74 Chlebowski RT, Hendrix SL, Langer RD, Stefanick ML, Gass M, Lane D, Rodabough RJ, Gilligan MA, Cyr MG, Thomson CA, Khandekar J, Petrovitch H, McTiernan A: Influence of estrogen plus progestin on breast cancer and mammography in healthy postmenopausal women: the Women's Health Initiative Randomized Trial. JAMA 2003;289:3243-3253.

75 Wassertheil-Smoller S, Hendrix SL, Limacher M, Heiss G, Kooperberg C, Baird A, Kotchen T, Curb JD, Black H, Rossouw JE, Aragaki A, Safford M, Stein E, Laowattana S, Mysiw WJ: Effect of estrogen plus progestin on stroke in postmenopausal women: the Women's Health Initiative: a randomized trial. JAMA 2003;289:2673-2684.

76 MacLennan AH, Henderson VW, Paine BJ, Mathias J, Ramsay EN, Ryan P, Stocks NP, Taylor AW: Hormone therapy, timing of initiation, and cognition in women aged older than 60 years: the REMEMBER pilot study. Menopause 2006;13:28-36.

77 Miida T, Takahashi A, Tanabe N, Ikeuchi T: Can statin therapy really reduce the risk of Alzheimer's disease and slow its progression? Curr Opin Lipidol 2005;16:619-623.

78 Drachman D: Preventing and treating Alzheimer's disease: strategies and prospects. Exp Rev Neurotherapeut 2003;3:565-569.
79 Simons M, Schwarzler F, Lutjohann D, von Bergmann K, Beyreuther K, Dichgans J, Wormstall H, Hartmann T, Schulz JB: Treatment with simvastatin in normocholesterolemic patients with Alzheimer's disease: a 26-week randomized, placebo-controlled, double-blind trial. Ann Neurol 2002;52: 346-350.

80 Sparks DL, Sabbagh MN, Connor DJ, Lopez J, Launer LJ, Browne P, Wasser D, JohnsonTraver S, Lochhead J, Ziolwolski C: Atorvastatin for the treatment of mild to moderate Alzheimer disease: preliminary results. Arch Neurol 2005;62:753-757.

81 Algotsson A, Winblad B: Patients with Alzheimer's disease may be particularly susceptible to adverse effects of statins. Dement Geriatr Cogn Disord 2004;17:109-116.

-82 Yon A, Scogin F: Procedures for identifying evidence-based psychological treatments for older adults. Psychol Aging 2007;22:4-7.

83 Sitzer DI, Twamley EW, Jeste DV: Cognitive training in Alzheimer's disease: a meta-analysis of the literature. Acta Psychiatr Scand 2006;114:75-90.

84 Spector A, Orrell M, Davies S, Woods B: Reality orientation for dementia. Cochrane $\mathrm{Da}-$ tabase Syst Rev 2000:CD001119.

85 Spector A, Thorgrimsen L, Woods B, Royan L, Davies S, Butterworth M, Orrell M: Efficacy of an evidence-based cognitive stimulation therapy programme for people with dementia: randomised controlled trial. $\mathrm{Br} \mathrm{J}$ Psychiatry 2003;183:248-254.

86 Logsdon RG, McCurry SM, Teri L: Evidencebased psychological treatments for disruptive behaviors in individuals with dementia. Psychol Aging 2007;22:28-36.

87 Gallagher-Thompson D, Coon DW: Evidence-based psychological treatments for distress in family caregivers of older adults. Psychol Aging 2007;22:37-51.

88 Gomez-Isla T, Price JL, McKeel DW Jr, Morris JC, Growdon JH, Hyman BT: Profound loss of layer II entorhinal cortex neurons occurs in very mild Alzheimer's disease. J Neurosci 1996;16:4491-4500.

-89 Morris JC, Storandt M, McKeel DW Jr, Rubin EH, Price JL, Grant EA, Berg L: Cerebral amyloid deposition and diffuse plaques in 'normal' aging: evidence for presymptomatic and very mild Alzheimer's disease. Neurology 1996;46:707-719.

90 Mondadori CR, Buchmann A, Mustovic H, Schmidt CF, Boesiger P, Nitsch RM, Hock C, Streffer J, Henke K: Enhanced brain activity may precede the diagnosis of Alzheimer's disease by 30 years. Brain 2006;129:29082922

-91 Ingelsson M, Fukumoto H, Newell KL, Growdon JH, Hedley-Whyte ET, Frosch MP, Albert MS, Hyman BT, Irizarry MC: Early Abeta accumulation and progressive synaptic loss, gliosis, and tangle formation in $\mathrm{AD}$ brain. Neurology 2004;62:925-931. 
92 DeKosky S: Early intervention is key to successful management of Alzheimer disease. Alzheimer Dis Assoc Disord 2003;17(suppl 4):S99-S104.

$\checkmark 93$ Winblad B, Palmer K, Kivipelto M, Jelic V, Fratiglioni L, Wahlund LO, Nordberg A, Backman L, Albert M, Almkvist O, Arai H, Basun H, Blennow K, de Leon M, DeCarli C, Erkinjuntti T, Giacobini E, Graff C, Hardy J, Jack C, Jorm A, Ritchie K, van Duijn C, Visser P, Petersen RC: Mild cognitive impairment - beyond controversies, towards a consensus: report of the International Working Group on Mild Cognitive Impairment. J Intern Med 2004;256:240-246.

94 Petersen RC: Mild cognitive impairment as a diagnostic entity. J Intern Med 2004;256: 183-194.

95 Gauthier S, Reisberg B, Zaudig M, Petersen RC, Ritchie K, Broich K, Belleville S, Brodaty $\mathrm{H}$, Bennett $\mathrm{D}$, Chertkow $\mathrm{H}$, Cummings JL, de Leon M, Feldman H, Ganguli M, Hampel H, Scheltens P, Tierney MC, Whitehouse P, Winblad B: Mild cognitive impairment. Lancet 2006;367:1262-1270.

\$6 Petersen RC, Smith GE, Waring SC, Ivnik RJ, Tangalos EG, Kokmen E: Mild cognitive impairment: clinical characterization and outcome. Arch Neurol 1999;56:303-308.

$\checkmark 97$ Fischer P, Jungwirth S, Zehetmayer S, Weissgram S, Hoenigschnabl S, Gelpi E, Krampla W, Tragl KH: Conversion from subtypes of mild cognitive impairment to Alzheimer dementia. Neurology 2007;68: 288-291.

\$98 Tabert MH, Manly JJ, Liu X, Pelton GH, Rosenblum S, Jacobs M, Zamora D, Goodkind M, Bell K, Stern Y, Devanand DP: Neuropsychological prediction of conversion to Alzheimer disease in patients with mild cognitive impairment. Arch Gen Psy chiatry 2006;63:916-924

$\checkmark 99$ Palmer K, Berger AK, Monastero R, Winblad B, Backman L, Fratiglioni L: Predictors of progression from mild cognitive impairment to Alzheimer disease. Neurology 2007;68:1596-1602.

-100 Lopez OL, Kuller LH, Becker JT, Dulberg C, Sweet RA, Gach HM, Dekosky ST: Incidence of dementia in mild cognitive impairment in the cardiovascular health study cognition study. Arch Neurol 2007;64:416-420.

101 Schonknecht P, Pantel J, Kaiser E, Thomann P, Schroder J: Increased tau protein differentiates mild cognitive impairment from geriatric depression and predicts conversion to dementia. Neurosci Lett 2007; 416:39-42.

-102 Dubois B, Feldman HH, Jacova C, Dekosky ST, Barberger-Gateau P, Cummings J, Delacourte A, Galasko D, Gauthier S, Jicha G, Meguro K, O’Brien J, Pasquier F, Robert P, Rossor M, Salloway S, Stern Y, Visser PJ, Scheltens P: Research criteria for the diagnosis of Alzheimer's disease: revising the NINCDS-ADRDA criteria. Lancet Neurol 2007;6:734-746
103 Petersen RC, Doody R, Kurz A, Mohs RC, Morris JC, Rabins PV, Ritchie K, Rossor M, Thal L, Winblad B: Current concepts in mild cognitive impairment. Arch Neurol 2001;58:1985-1992.

104 Daly E, Zaitchik D, Copeland M, Schmahmann J, Gunther J, Albert M: Predicting conversion to Alzheimer disease using standardized clinical information. Arch Neurol 2000;57:675-680.

105 Garand L, Dew MA, Eazor LR, DeKosky ST, Reynolds CF 3rd: Caregiving burden and psychiatric morbidity in spouses of persons with mild cognitive impairment. Int J Geriatr Psychiatry 2005;20:512-522.

106 Ready RE, Ott BR, Grace J: Patient versus informant perspectives of Quality of Life in Mild Cognitive Impairment and Alzheimer's disease. Int J Geriatr Psychiatry 2004; 19:256-265.

107 Olazaran J, Muniz R, Reisberg B, Pena-Casanova J, del Ser T, Cruz-Jentoft AJ, Serrano P, Navarro E, Garcia de la Rocha ML, Frank A, Galiano M, Fernandez-Bullido Y, Serra JA, Gonzalez-Salvador MT, Sevilla C: Benefits of cognitive-motor intervention in MCI and mild to moderate Alzheimer disease. Neurology 2004;63:2348-2353.

108 Ready RE, Ott BR, Grace J: Validity of informant reports about $\mathrm{AD}$ and MCI patients' memory. Alzheimer Dis Assoc Disord 2004;18:11-16.

109 Scheltens P, Korf ES: Contribution of neuroimaging in the diagnosis of Alzheimer's disease and other dementias. Curr Opin Neurol 2000;13:391-396.

110 Chang CY, Silverman DH: Accuracy of early diagnosis and its impact on the management and course of Alzheimer's disease. Expert Rev Mol Diagn 2004;4:63-69.

$>111$ Dougall NJ, Bruggink S, Ebmeier KP: Systematic review of the diagnostic accuracy of 99mTc-HMPAO-SPECT in dementia. Am J Geriatr Psychiatry 2004;12:554-570.

-112 Kantarci K, Jack CR Jr: Neuroimaging in Alzheimer disease: an evidence-based review. Neuroimaging Clin N Am 2003;13: 197-209.

113 Silverman DH, Gambhir SS, Huang HW, Schwimmer J, Kim S, Small GW, Chodosh J, Czernin J, Phelps ME: Evaluating early dementia with and without assessment of regional cerebral metabolism by PET: a comparison of predicted costs and benefits. J Nucl Med 2002;43:253-266.

114 McMahon PM, Araki SS, Sandberg EA, Neumann PJ, Gazelle GS: Cost-effectiveness of PET in the diagnosis of Alzheimer disease. Radiology 2003;228:515-522.

115 McMahon PM, Araki SS, Neumann PJ, Harris GJ, Gazelle GS: Cost-effectiveness of functional imaging tests in the diagnosis of Alzheimer disease. Radiology 2000;217: 58-68.

116 Lorentz WJ, Scanlan JM, Borson S: Brief screening tests for dementia. Can J Psychiatry 2002;47:723-733.
117 Tariq SH, Tumosa N, Chibnall JT, Perry MH 3rd, Morley JE: Comparison of the Saint Louis University Mental Status Examination and the Mini-Mental State Examination for detecting dementia and mild neurocognitive disorder - a pilot study. Am J Geriatr Psychiatry 2006;14:900-910.

118 Dubois B, Feldman HH, Jacova C, Dekosky ST, Barberger-Gateau P, Cummings J, Delacourte A, Galasko D, Gauthier S, Jicha G, Meguro K, O’Brien J, Pasquier F, Robert P, Rossor M, Salloway S, Stern Y, Visser PJ, Scheltens P: Research criteria for the diagnosis of Alzheimer's disease: revising the NINCDS-ADRDA criteria. Lancet Neurol 2007;6:734-746.

119 Gatz M, Prescott CA, Pedersen NL: Lifestyle risk and delaying factors. Alzheimer Dis Assoc Disord 2006;20:S84-S88.

120 Whitmer RA, Gunderson EP, Barrett-Connor E, Quesenberry CP Jr, Yaffe K: Obesity in middle age and future risk of dementia: a 27 year longitudinal population based study. BMJ 2005;330:1360.

121 Whitmer RA, Gunderson EP, Quesenberry CP Jr, Zhou J, Yaffe K: Body mass index in midlife and risk of Alzheimer disease and vascular dementia. Curr Alzheimer Res 2007;4:103-109.

122 Gatz M, Mortimer JA, Fratiglioni L, Johansson B, Berg S, Andel R, Crowe M, Fiske A, Reynolds CA, Pedersen NL: Accounting for the relationship between low education and dementia: a twin study. Physiol Behav 2007;92:232-237.

123 Kivipelto M, Ngandu T, Laatikainen T, Winblad B, Soininen H, Tuomilehto J: Risk score for the prediction of dementia risk in 20 years among middle aged people: a longitudinal, population-based study. Lancet Neurol 2006;5:735-741.

124 Orgogozo JM, Dartigues JF, Lafont S, Letenneur L, Commenges D, Salamon R, Renaud S, Breteler MB: Wine consumption and dementia in the elderly: a prospective community study in the Bordeaux area. Rev Neurol (Paris) 1997;153:185-192.

-125 Anekonda TS: Resveratrol - a boon for treating Alzheimer's disease? Brain Res Brain Res Rev 2006;52:316-326.

$>126$ Dai Q, Borenstein AR, Wu Y, Jackson JC, Larson EB: Fruit and vegetable juices and Alzheimer's disease: the Kame Project. Am J Med 2006;119:751-759.

127 Rezai-Zadeh K, Shytle D, Sun N, Mori T, Hou H, Jeanniton D, Ehrhart J, Townsend K, Zeng J, Morgan D, Hardy J, Town T, Tan $\mathrm{J}$ : Green tea epigallocatechin-3-gallate (EGCG) modulates amyloid precursor protein cleavage and reduces cerebral amyloidosis in Alzheimer transgenic mice. J Neurosci 2005;25:8807-8814 
128 Arendash GW, Schleif W, Rezai-Zadeh K, Jackson EK, Zacharia LC, Cracchiolo JR, Shippy D, Tan J: Caffeine protects Alzheimer's mice against cognitive impairment and reduces brain beta-amyloid production. Neuroscience 2006;142:941-952.

129 Lindsay J, Laurin D, Verreault R, Hebert R, Helliwell B, Hill GB, McDowell I: Risk factors for Alzheimer's disease: a prospective analysis from the Canadian Study of Health and Aging. Am J Epidemiol 2002;156:445453.

130 Lim GP, Chu T, Yang F, Beech W, Frautschy SA, Cole GM: The curry spice curcumin reduces oxidative damage and amyloid pathology in an Alzheimer transgenic mouse. J Neurosci 2001;21:8370-8377.

-131 Yang F, Lim GP, Begum AN, Ubeda OJ, Simmons MR, Ambegaokar SS, Chen PP, Kayed R, Glabe CG, Frautschy SA, Cole GM: Curcumin inhibits formation of amyloid beta oligomers and fibrils, binds plaques, and reduces amyloid in vivo. J Biol Chem 2005;280:5892-5901.

-132 Morris MC, Evans DA, Bienias JL, Tangney CC, Bennett DA, Wilson RS, Aggarwal N, Schneider J: Consumption of fish and n-3 fatty acids and risk of incident Alzheimer disease. Arch Neurol 2003;60:940-946.

-133 Morris MC, Evans DA, Tangney CC, Bienias JL, Wilson RS: Fish consumption and cognitive decline with age in a large community study. Arch Neurol 2005;62:18491853.

134 Morris MC, Evans DA, Bienias JL, Tangney CC, Bennett DA, Aggarwal N, Schneider J, Wilson RS: Dietary fats and the risk of incident Alzheimer disease. Arch Neurol 2003;60:194-200.

135 Verghese J, Lipton RB, Katz MJ, Hall CB, Derby CA, Kuslansky G, Ambrose AF, Sliwinski M, Buschke $\mathrm{H}$ : Leisure activities and the risk of dementia in the elderly. $\mathrm{N}$ Engl J Med 2003;348:2508-2516.

136 Larson EB, Wang L, Bowen JD, McCormick WC, Teri L, Crane P, Kukull W: Exercise is associated with reduced risk for incident dementia among persons 65 years of age and older. Ann Intern Med 2006;144:73-81.

$\checkmark 137$ Cotman CW, Berchtold NC: Exercise: a behavioral intervention to enhance brain health and plasticity. Trends Neurosci 2002;25:295-301.

138 Abbott RD, White LR, Ross GW, Masaki $\mathrm{KH}$, Curb JD, Petrovitch H: Walking and dementia in physically capable elderly men. JAMA 2004;292:1447-1453.

-139 Weuve J, Kang JH, Manson JE, Breteler MM, Ware JH, Grodstein F: Physical activity, including walking, and cognitive function in older women. JAMA 2004;292: 1454-1461.

140 Heyn P, Abreu BC, Ottenbacher KJ: The effects of exercise training on elderly persons with cognitive impairment and dementia: a meta-analysis. Arch Phys Med Rehabil 2004;85:1694-1704.
141 Fratiglioni L, Paillard-Borg S, Winblad B: An active and socially integrated lifestyle in late life might protect against dementia. Lancet Neurol 2004;3:343-353.

142 Mittelman MS, Haley WE, Clay OJ, Roth DL: Improving caregiver well-being delays nursing home placement of patients with Alzheimer disease. Neurology 2006;67: 1592-1599.

143 Mittelman MS, Roth DL, Haley WE, Zarit SH: Effects of a caregiver intervention on negative caregiver appraisals of behavior problems in patients with Alzheimer's disease: results of a randomized trial. J Gerontol B Psychol Sci Soc Sci 2004;59:P27-P34.

144 Roth DL, Mittelman MS, Clay OJ, Madan A, Haley WE: Changes in social support as mediators of the impact of a psychosocial intervention for spouse caregivers of persons with Alzheimer's disease. Psychol Aging 2005;20:634-644.

145 Jang Y, Clay OJ, Roth DL, Haley WE, Mittelman MS: Neuroticism and longitudinal change in caregiver depression: impact of a spouse-caregiver intervention program. Gerontologist 2004;44:311-317.

146 Mittelman MS, Roth DL, Coon DW, Haley WE: Sustained benefit of supportive intervention for depressive symptoms in caregivers of patients with Alzheimer's disease. Am J Psychiatry 2004;161:850-856.

147 Belle SH, Burgio L, Burns R, Coon D, Czaja SJ, Gallagher-Thompson D, Gitlin LN, Klinger J, Koepke KM, Lee CC, Martindale-Adams J, Nichols L, Schulz R, Stahl S, Stevens A, Winter L, Zhang S: Enhancing the quality of life of dementia caregivers from different ethnic or racial groups: a randomized, controlled trial. Ann Intern Med 2006;145:727-738.

148 Sorensen S, Duberstein P, Gill D, Pinquart M: Dementia care: mental health effects, intervention strategies, and clinical implications. Lancet Neurol 2006;5:961-973.

149 Gauthier S, Emre M, Farlow MR, Bullock R, Grossberg GT, Potkin SG: Strategies for continued successful treatment of Alzheimer's disease: switching cholinesterase inhibitors. Curr Med Res Opin 2003;19: 707-714.

150 SDI Alzheimer's Disease Patient Persistency and Compliance Study (August 2006 Update): NPA, IMS; August 2006.

151 Seltzer B: Donepezil: an update. Expert Opin Pharmacother 2007;8:1011-1023.

152 Emre M: Switching cholinesterase inhibitors in patients with Alzheimer's disease. Int J Clin Pract Suppl 2002:64-72.

153 Morris JC, Farlow MR, Ferris SH, Kurz AF, Maelicke A, Rasmusen L, Wilkinson D, Yan B: Therapeutic continuity in Alzheimer's disease: switching patients to galantamine. Panel discussion: recommendations for prescribers. Clin Ther 2001;23(suppl A): A31-A39.
154 Winblad B, Kilander L, Eriksson S, Minthon L, Batsman S, Wetterholm AL, Jansson-Blixt C, Haglund A: Donepezil in patients with severe Alzheimer's disease: double-blind, parallel-group, placebocontrolled study. Lancet 2006;367:10571065.

155 Schmitt FA, Wichems CH: A systematic review of assessment and treatment of moderate to severe Alzheimer's disease. Prim Care Companion J Clin Psychiatry 2006;8: 158-159.

156 Feldman HH, Ferris S, Winblad B, Sfikas $\mathrm{N}$, Mancione L, He Y, Tekin S, Burns A, Cummings J, del Ser T, Inzitari D, Orgogozo JM, Sauer H, Scheltens P, Scarpini E, Herrmann N, Farlow M, Potkin S, Charles HC, Fox NC, Lane R: Effect of rivastigmine on delay to diagnosis of Alzheimer's disease from mild cognitive impairment: the InDDEx study. Lancet Neurol 2007;6:501512.

157 Birks J, Flicker L: Donepezil for mild cognitive impairment. Cochrane Database Syst Rev 2006;3:CD006104.

158 Lipton SA: Paradigm shift in neuroprotection by NMDA receptor blockade: memantine and beyond. Nat Rev Drug Discov 2006;5:160-170.

159 Hartmann S, Mobius HJ: Tolerability of memantine in combination with cholinesterase inhibitors in dementia therapy. Int Clin Psychopharmacol 2003;18:81-85.

160 Pass MD, Shua-Haim JR, Patel P, Smith J: Safety, tolerability and caregiver's impressions of combination therapy with galantamine and memantine for the treatment of Alzheimer's disease (Abstract). Neurobiol Aging 2004;25(suppl 2):S210.

161 Riepe MW, Adler G, Ibach B, Weinkauf B, Gunay I, Tracik F: Adding memantine to rivastigmine therapy in patients with mildto-moderate Alzheimer's disease: results of a 12-week, open-label pilot study. Prim Care Companion J Clin Psychiatry 2006;8: 258-263.

162 Hien le TT, Cumming RG, Cameron ID, Chen JS, Lord SR, March LM, Schwarz J, Le Couteur DG, Sambrook PN: Atypical antipsychotic medications and risk of falls in residents of aged care facilities. J Am Geriatr Soc 2005;53:1290-1295.

163 Nelson JC: Increased risk of cerebrovascular adverse events and death in elderly demented patients treated with atypical antipsychotics: what's a clinician to do? J Clin Psychiatry 2005;66:1071.

-164 Schneider LS, Tariot PN, Dagerman KS, Davis SM, Hsiao JK, Ismail MS, Lebowitz BD, Lyketsos CG, Ryan JM, Stroup TS, Sultzer DL, Weintraub D, Lieberman JA, the CATIE-AD Study Group: Effectiveness of atypical antipsychotic drugs in patients with Alzheimer's disease. N Engl J Med 2006;355:1525-1538. 
165 Cummings JL, Frank JC, Cherry D, Kohatsu ND, Kemp B, Hewett L, Mittman B: Guidelines for managing Alzheimer's disease. II. Treatment. Am Fam Physician 2002;65:2525-2534.

166 Trinh NH, Hoblyn J, Mohanty S, Yaffe K: Efficacy of cholinesterase inhibitors in the treatment of neuropsychiatric symptoms and functional impairment in Alzheimer disease: a meta-analysis. JAMA 2003;289: 210-216.

167 Grossberg GT: Effect of rivastigmine in the treatment of behavioral disturbances associated with dementia: review of neuropsychiatric impairment in neuropsychiatric impairment in Alzheimer's disease. Curr Med Res Opin 2005;21:1631-1639.

168 Bonelli RM, Hofmann P, Aschoff A, Niederwieser G, Heuberger C, Jirikowski G, Kapfhammer HP: The influence of psychotropic drugs on cerebral cell death: female neurovulnerability to antipsychotics. Int Clin Psychopharmacol 2005;20:145-149.

169 Onder G, Zanetti O, Giacobini E, Frisoni GB, Bartorelli L, Carbone G, Lambertucci P, Silveri MC, Bernabei R: Reality orientation therapy combined with cholinesterase inhibitors in Alzheimer's disease: randomised controlled trial. Br J Psychiatry 2005; 187:450-455.

-170 Doody RS, Geldmacher DS, Gordon B, Perdomo CA, Pratt RD: Open-label, multicenter, phase 3 extension study of the safety and efficacy of donepezil in patients with Alzheimer disease. Arch Neurol 2001;58: 427-433.

-171 Reisberg B, Doody R, Stoffler A, Schmitt F, Ferris S, Mobius HJ: A 24-week open-label extension study of memantine in moderate to severe Alzheimer disease. Arch Neurol 2006;63:49-54.
172 Pirttila T, Wilcock G, Truyen L, Damaraju $\mathrm{CV}$ : Long-term efficacy and safety of galantamine in patients with mild-to-moderate Alzheimer's disease: multicenter trial. Eur J Neurol 2004;11:734-741.

173 Winblad B, Wimo A, Engedal K, Soininen H, Verhey F, Waldemar G, Wetterholm AL, Haglund A, Zhang R, Schindler R: 3-year study of donepezil therapy in Alzheimer's disease: effects of early and continuous therapy. Dement Geriatr Cogn Disord 2006;21:353-363.

174 Farlow MR, Lilly ML: Rivastigmine: an open-label, observational study of safety and effectiveness in treating patients with Alzheimer's disease for up to 5 years. BMC Geriatr 2005;5:3.

175 Cummings JL, Frank JC, Cherry D, Kohatsu ND, Kemp B, Hewett L, Mittman B Guidelines for managing Alzheimer's disease. I. Assessment. Am Fam Physician 2002;65:2263-2272.

176 Rogers SL, Doody RS, Mohs RC, Friedhoff LT: Donepezil improves cognition and global function in Alzheimer disease: a 15 week, double-blind, placebo-controlled study. Donepezil Study Group. Arch Intern Med 1998;158:1021-1031.

177 Rogers SL, Farlow MR, Doody RS, Mohs R, Friedhoff LT: A 24-week, double-blind, placebo-controlled trial of donepezil in patients with Alzheimer's disease. Donepezil Study Group. Neurology 1998;50:136-145.
178 Corey-Bloom J, Anand J, Veach J: A randomized trial evaluating the efficacy and safety of ENA 713 (rivastigmine tartrate), a new acetylcholinesterase inhibitor, in patients with mild to moderately severe Alzheimer's disease. International Journal of Geriatric Psychopharmacology 1998;1:5565.

179 Rosler M, Anand R, Cicin-Sain A, Gauthier S, Agid Y, Dal-Bianco P, Stahelin HB, Hartman R, Gharabawi M: Efficacy and safety of rivastigmine in patients with Alzheimer's disease: international randomised controlled trial. BMJ 1999;318:633-638.

180 Raskind MA, Peskind ER, Wessel T, Yuan W: Galantamine in AD: A 6-month randomized, placebo-controlled trial with a 6month extension. The Galantamine USA-1 Study Group. Neurology 2000;54:22612268.

181 Tariot PN, Solomon PR, Morris JC, Kershaw P, Lilienfeld S, Ding C: A 5-month, randomized, placebo-controlled trial of galantamine in $\mathrm{AD}$. The Galantamine USA-10 Study Group. Neurology 2000; 5:2269-2276

182 Wilcock GK, Lilienfeld S, Gaens E: Efficacy and safety of galantamine in patients with mild to moderate Alzheimer's disease: multicentre randomised controlled trial. Galantamine International-1 Study Group. BMJ 2000;321:1445-1449.

183 Rockwood K, Mintzer J, Truyen L, Wessel T, Wilkinson D: Effects of a flexible galantamine dose in Alzheimer's disease: a randomised, controlled trial. J Neurol Neurosurg Psychiatry 2001;7:589-895. 